\title{
The effect of crossing New Zealand White with Californian rabbits on growth and slaughter traits
}

\author{
DOROTA MAJ'1, JÓZEF BIENIEK ${ }^{1}$, PIOTR ŁAPA ${ }^{1}$ and INA STERNSTEIN²
}

\begin{abstract}
${ }^{1}$ Department of Genetics and Animal Breeding, Agriculture University of Krakow, Krakow, Poland, ${ }^{2}$ Department of Breeding Biology and Molecular Genetics, Institute of Animal Sciences, Agricultural and Horticultural Faculty, Humboldt-University of Berlin, Berlin, Germany
\end{abstract}

\section{Abstract}

The study was aimed to determine the effect of reciprocal-crossing rabbits on growth and slaughter traits. The experiment was conducted on 120 New Zealand White (NZW) and Californian (CAL) medium-sized rabbits and their $F_{1}$ reciprocal crosses (CAL $\times$ NZW and $\mathrm{NZW} \times(\mathrm{CAL})$. The rabbits were fed pellets ad libitum, and slaughtered at body weight around $2.5 \mathrm{~kg}$. The following traits were recorded: body weight and average daily gain at birth to slaughter, average feed consumption from weaning to slaughter, slaughter age, carcass weight, meat, bone and fat content of carcass, prime cuts weight (fore part, loin and hind part), and dressing percentage. The results indicated that reciprocal crossbred $\mathrm{CAL} \times \mathrm{NZW}$ and NZW $\times$ CAL rabbits were heavier than purebred animals. $\mathrm{NZW} \times \mathrm{CAL}$ crosses attained the slaughter body weight earlier, and had lower feed consumption. The dressing percentage in NZW $\times$ CAL crosses was highest, while the lowest in NZW rabbits. For other slaughter traits, except the fat content of carcass, effects of crossing rabbits were small. The magnitude of the crossbreeding effects depended on the direction of crossbreeding. Maximum effects in crosses for slaughter age, body weight, feed consumption and dressing percentage were obtained when the Californian breed was used as a maternal component.

Keywords: rabbit, genotype, growth, slaughter traits

\section{Zusammenfassung}

\section{Der Effekt der Kreuzung von Kaninchen der Rassen Weiße Neuseeländer und Kalifornier auf Wachstum und Schlachtmerkmale}

Ziel der Untersuchungen war es den Effekt von reziproken Kreuzungen beim Kaninchen auf Wachstums- und Schlachtmerkmale zu bestimmen. Der Versuch umfasste 120 Kaninchen der mittelgroßen Rassen Weiße Neuseeländer (NZW) und Kalifornier (CAL) und ihre reziproken $\mathrm{F}_{1}$ Kreuzungen $(C A L \times N Z W$ und NZW $\times C A L)$. Die Kaninchen wurde ad libitum mit Pellets gefüttert und mit einem Gewicht von ca. 2,5 kg geschlachtet. Folgende Merkmale wurden erfasst: Körpergewicht und tägliche Zunahme von Geburt bis zum Schlachtzeitpunkt, durchschnittliche Futterverwertung vom Absetzten bis zum Schlachtzeitpunkt, Schlachtalter, Schlachtkörpergewicht, Fleisch-, Knochen- und Fettgehalt des Schlachtkörpers, Anteil wertvoller Teilstücke (Vorderteil, Rücken, Hinderläufe) und Schlachtausbeute. Die Ergebnisse zeigten, dass die reziproken Kreuzungen CAL $\times$ NZW 
und NZW $\times$ CAL schwerer sind als die Reinzuchttiere. Die Kreuzung NZW $\times$ CAL erreicht das Schlachtgewicht früher und hat einen geringeren Futterverbrauch. Die Schlachtausbeute der NZW $\times$ CAL Kreuzungstiere lag am höchsten, demgegenüber erreichte dieses Merkmal den niedrigsten Wert bei den NZW. Für die anderen Schlachtmerkmale mit Ausnahme des Fettgehalts des Schlachtkörpers waren die Kreuzungseffekte gering. Die Größe der Kreuzungseffekte ist dabei abhängig von der Kreuzungsrichtung. Die höchsten Effekte für Schlachtalter, Körpergewicht, Futterverwertung und Schlachtausbeute in den Kreuzungen wurden für die Anpaarungen gefunden in denen die Kalifornische Rasse als maternale Komponente eingesetzt wurde.

Schlüsselwörter: Kaninchen, Genotyp, Wachstum, Schlachtmerkmale

\section{Introduction}

Rabbit meat is characterized by a high protein and low fat and cholesterol content and it is considered as a delicacy and a health food product (DALLE ZOTTE 2000). The production of rabbit meat is based on pure breeds selected for meat traits and on their crosses. The most popular breeds used in commercial rabbit production are mediumsized ones: New Zealand White and Californian (OZIMBA and LUKEFAHR 1991, SHEMEIS and ABDALLAH 1998). Selection for high growth rate in rabbits improves slaughter performance, but carries a high risk of lowering the quality of meat (PILES et al. 2000, SHEMEIS and ABDALLAH 2000, SHAHIN and HASSAN 2002). Shortening the time spent on the production of commercial carcasses and improving feed efficiency, dressing percentage and muscle characteristics are the most important optimization criteria for rabbit meat production (GONDRET et al. 2005, SHEMEIS and ABDALLAH 1998). Crossbreeding is one of the fast tools offered to the breeders to improve many traits in farm animals (NOFAL et al. 1997, OSENI et al. 1997).

The aim of the study was to determine the effect of crossbreeding on the growth and slaughter traits in rabbits.

\section{Material and methods}

\section{Animals}

The animals used in this experiment originated from the experimental rabbit farm at the Department of Genetics and Animal Breeding of the Agricultural University of Krakow. The experiment was conducted on 120 (30 rabbits per group, $50 \%$ of males and $50 \%$ of females in each group) New Zealand White (NZW) and Californian (CAL) medium-sized rabbits and their $\mathrm{F}_{1}$ reciprocal crosses ( ${ }^{A} \mathrm{CAL} \times \mp \mathrm{NZW}$ and ${ }^{-} \mathrm{NZW} \times \oplus \mathrm{CAL}$ ). These animals represented progeny of 5 sires and 15 dams in each group (one male and one female from each litter). The rabbits were fed (ad libitum) pellets containing $16.5 \%$ protein, max $14 \%$ crude fibre, and min $10.2 \mathrm{MJ}$ metabolizable energy. Kids were identified in the second week after birth. The animals were born in spring as a first litter and were weaned at 6 weeks of age. 


\section{Measurements}

The following traits were recorded: body weight at birth to slaughter, average daily gain from birth to slaughter, average feed consumption from weaning to slaughter, slaughter age, hot and cold carcass weight, meat, bone and fat content of carcass, prime cuts (fore part, loin and hind part) weight, and dressing percentage [(hot carcass weight + giblets weight) / slaughter weight] 100.

Litter sizes and weights were recorded at birth and at age 7 and 12 days, and then all animals were weighed weekly from day 14 to slaughter. Feed consumption was recorded each week from weaning to slaughter.

The Gompertz growth curve was fitted to the weight-age data of each rabbit by the nonlinear least squares procedure (SAS 2001). The equation for the Gompertz function has the following form:

$$
y(t)=A \mathrm{e}^{-B \mathrm{e}^{-k t}}
$$

where $y(t)$ is weight (in $\mathrm{g}$ ) at age $t$ (in days), $A, B, K$ are fitted parameters, and $\mathrm{e}$ is the base of the natural logarithm $(e=2.71828 \ldots)$. Parameter $A$ is interpreted as the asymptotic limit of the weight or the average mature weight of the rabbit, $K$ is the rate of maturing (the larger the value of $K$, the earlier the animal matures), and $B$ is a scaling parameter (constant of integration, related to the initial weight).

The animals were slaughtered when they reached body weight around $2.5 \mathrm{~kg}$, in compliance with Polish national regulations for commercial slaughtering. Rabbits were dissected according to methods described by BIENIEK (1997). Hot carcasses were suspended in a ventilated area for $30 \mathrm{~min}$, and then were cooled for $24 \mathrm{~h}$ at $4^{\circ} \mathrm{C}$, weighted and separated into the following parts: fore part - a cut between the last thoracic and the first lumbar vertebra, loin - a cut between the last thoracic and the first lumbar vertebra and between the last lumbar and the first sacral vertebra, hind part - determined by the latter cut.

\section{Statistical analysis}

To examine the differences between the means for genetic groups, the General Linear Model (GLM) procedure and Tukey's test (SAS 2001) were used. The linear model included genetic group and sex as fixed effects, and litter size and rabbit age at slaughter as linear covariates. Results are expressed as the means and their standard deviations.

\section{Results}

The growth curves estimated using the Gompertz function for NZW and CAL rabbits and their reciprocal crosses are shown in Figure 1. The four genotypes had similar growth curves, especially at earlier ages. From weaning to slaughter the crosses grew faster than the purebred rabbits. Genotype had a significant effect on body weight at the age of 70 days to slaughter. The body weight of NZW $\times$ CAL crosses was the highest and it differed significantly from NZW and CAL rabbits $(P \leq 0.01)$. Body weight of CAL rabbits was the lowest. 


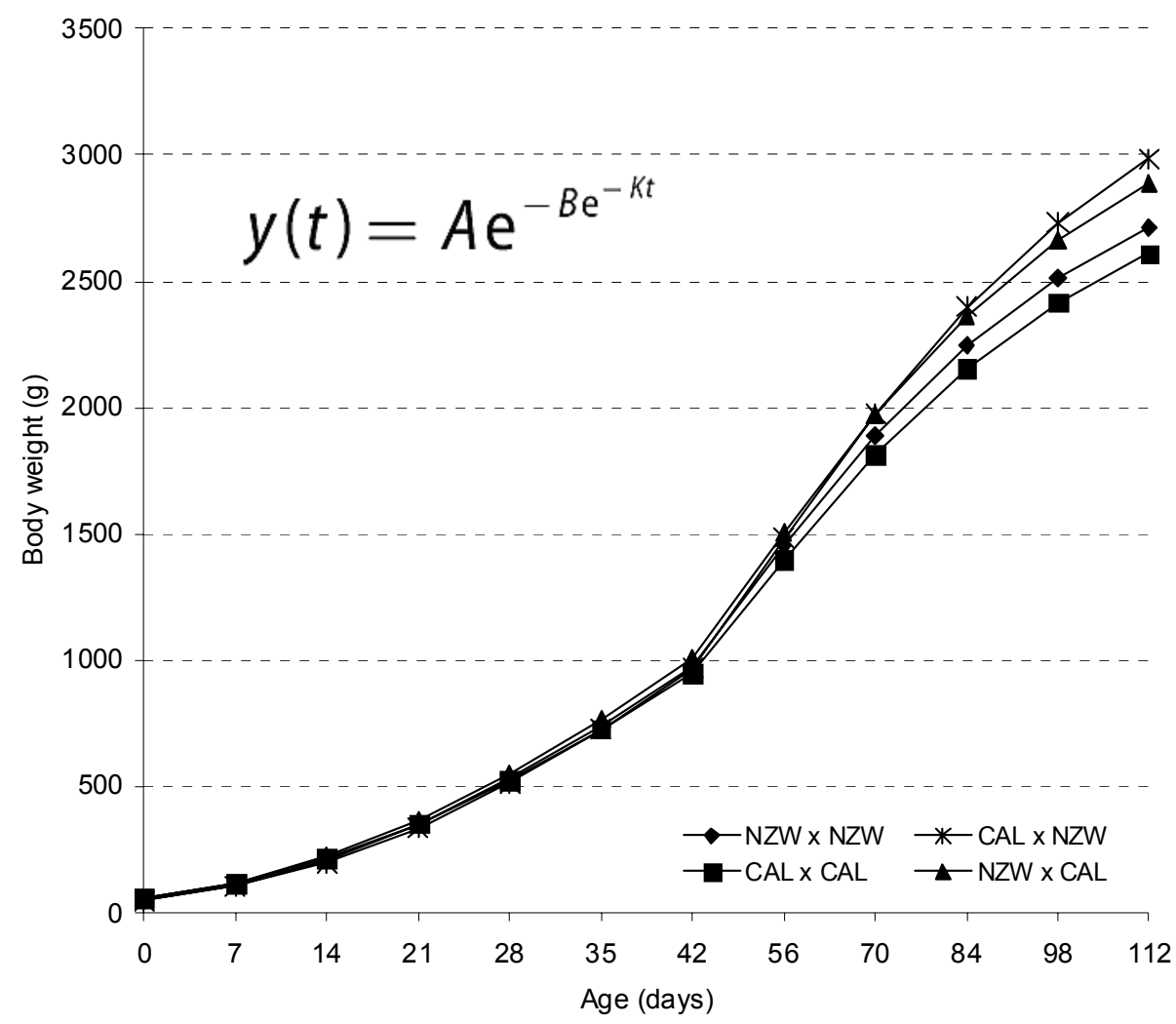

Figure 1

Body weight of rabbits (by Gompertz growth curve)

Geschätze Wachstumskurven für Körpergewichte von Kaninchen - Gompertzfunktion

The rabbits differed in some slaughter traits (Table 1).

Significant differences were found in slaughter age and in feed intake per $1 \mathrm{~kg}$ of gain from weaning to slaughter. Crosses NZW $\times$ CAL consumed less feed per unit gain than purebred rabbits and CAL $\times$ NZW crosses $(P \leq 0.05)$ and reached the slaughter weight of $2.5 \mathrm{~kg}$ earliest, followed by CAL $\times$ NZW crosses and NZW and CAL purebred. The average daily gain from birth to slaughter was similar for all genetic groups.

No differences between purebred rabbits and crosses were found in carcass weight (hot and cold), the trait exhibited a low variability (Table 1). The meat weight of the carcass was greater $(P \leq 0.05)$ in NZW $\times$ CAL crosses than in purebred NZW. Purebred rabbits did not differ significantly from crosses in the bone content of carcass. The rabbit carcasses had a small dissectible fat content (1.3-2.5\%) which was significantly lower in NZW rabbits than in animals from other genetic groups $(P \leq 0.05)$. The fat content of carcass displayed a wide variability.

The breeds did not differ in the weight of the fore part of carcass. Purebred NZW developed the most valuable cuts (loin and the hind part of the carcass) significantly worse than crosses and CAL purebred rabbits. As the carcass prime cuts and the carcass 
meat and bone content were corrected for reference carcass weight their variability was low and they did not differ significantly between purebred and crossbred rabbits.

Dressing percentage was influenced by genotype $(P \leq 0.05)$. It was highest in crossbred $\mathrm{NZW} \times \mathrm{CAL}$, and the lowest in purebred NZW rabbits.

Sex did not have any significant influence on growth and slaughter traits (untabulated).

Table 1

Slaughter traits of rabbits (mean \pm sd)

Schlachtmerkmale der Kaninchen (Mittelwerte \pm sd)

\begin{tabular}{lccccc}
\hline \multirow{2}{*}{ Trait } & & \multicolumn{3}{c}{ Genetic group } & \\
& $\mathrm{NZW} \times \mathrm{NZW}$ & $\mathrm{CAL} \times \mathrm{CAL}$ & $\mathrm{CAL} \times \mathrm{NZW}$ & $\mathrm{NZW} \times \mathrm{CAL}$ & \\
\hline$n$ & 30 & 30 & 30 & 30 & \\
Slaughter age, days & $97 \pm 14^{\mathrm{ab}}$ & $105 \pm 17^{\mathrm{a}}$ & $96 \pm 13^{\mathrm{ab}}$ & $94 \pm 12^{\mathrm{b}}$ & $*$ \\
Feed intake, kg/kg gain & $4.18 \pm 0.43^{\mathrm{b}}$ & $4.20 \pm 0.45^{\mathrm{b}}$ & $4.08 \pm 0.42^{\mathrm{b}}$ & $3.60 \pm 0.38^{\mathrm{a}}$ & $*$ \\
Daily gain, g & $23.6 \pm 8.4$ & $23.1 \pm 8.4$ & $25.0 \pm 8.7$ & $25.1 \pm 8.8$ & $\mathrm{~ns}$ \\
Hot carcass weight, g & $1205.0 \pm 80.3$ & $1270.2 \pm 103.2$ & $1235.7 \pm 94.3$ & $1268.7 \pm 60.6$ & $\mathrm{~ns}$ \\
Cold carcass weight, g & $1171.0 \pm 79.1$ & $1232.0 \pm 94.8$ & $1202.9 \pm 92.2$ & $1231.2 \pm 57.1$ & $\mathrm{~ns}$ \\
Carcass content, g & & & & & \\
- meat & $941.1 \pm 68.2^{\mathrm{a}}$ & $985.5 \pm 72.4^{\mathrm{ab}}$ & $963.5 \pm 76.2^{\mathrm{ab}}$ & $987.1 \pm 47.5^{\mathrm{b}}$ & $*$ \\
- bone & $212.5 \pm 17.2$ & $212.4 \pm 22.4$ & $209.0 \pm 19.8$ & $216.8 \pm 23.9$ & $\mathrm{~ns}$ \\
Carcass content, \% & & & & & \\
- meat & $80.4 \pm 0.02$ & $80.0 \pm 0.02$ & $80.1 \pm 0.02$ & $80.2 \pm 0.02$ & $\mathrm{~ns}$ \\
- bone & $18.2 \pm 1.4$ & $17.3 \pm 1.5$ & $17.4 \pm 1.2$ & $17.6 \pm 1.8$ & $\mathrm{~ns}$ \\
- fat & $1.3 \pm 1.2^{\mathrm{a}}$ & $2.5 \pm 1.9^{\mathrm{b}}$ & $2.5 \pm 1.6^{\mathrm{b}}$ & $2.0 \pm 1.2^{\mathrm{ab}}$ & $*$ \\
Carcass prime cut, g & & & & & \\
- fore part & $461.9 \pm 38.5$ & $478.6 \pm 42.2$ & $474.6 \pm 47.5$ & $478.8 \pm 26.7$ & $\mathrm{~ns}$ \\
- loin & $263.2 \pm 20.6^{\mathrm{a}}$ & $286.6 \pm 32.3^{\mathrm{b}}$ & $275.1 \pm 27.8^{\mathrm{ab}}$ & $283.6 \pm 22.4^{\mathrm{b}}$ & $*$ \\
- hind part & $445.4 \pm 29.4^{\mathrm{a}}$ & $466.2 \pm 33.0^{\mathrm{b}}$ & $452.7 \pm 32.8^{\mathrm{ab}}$ & $467.9 \pm 26.6^{\mathrm{b}}$ & $*$ \\
Carcass prime cut, \% & & & & & \\
- fore part & $39.4 \pm 1.3$ & $38.8 \pm 1.3$ & $39.4 \pm 1.5$ & $38.9 \pm 1.2$ & $\mathrm{~ns}$ \\
- loin & $22.5 \pm 1.2$ & $23.2 \pm 1.3$ & $22.9 \pm 1.6$ & $23.0 \pm 1.5$ & $\mathrm{~ns}$ \\
- hind part & $38.1 \pm 0.9$ & $37.9 \pm 1.3$ & $37.7 \pm 1.4$ & $38.0 \pm 1.2$ & $\mathrm{~ns}$ \\
Dressing percentage & $53.1 \pm 1.7^{\mathrm{a}}$ & $54.6 \pm 2.4^{\mathrm{ab}}$ & $54.0 \pm 1.9^{\mathrm{ab}}$ & $55.1 \pm 2.4^{\mathrm{b}}$ & $*$ \\
\hline
\end{tabular}

ns non significant, ${ }^{*} P \leq 0.05$, means in the same row with different superscripts differ significantly

\section{Discussion}

The results of the experiment showed that crossing NZW and CAL rabbits had a positive effect on growth and slaughter traits. In spite of similar origin of the NZW and CAL rabbits, the crosses grew faster and reached market weight earlier than the purebred rabbits. These results are in agreement with those of Ozimba and Lukefahr (1991). Using NZW and CAL purebreds and several different crossbreds they found purebreds to have lower slaughter and carcass weight.

Carcass traits are basically influenced by adult weight and the maturity of rabbits at slaughter (PILES et al. 2000, DALLE ZOTTE 2002). Though rabbit carcasses are usually commercialized as a whole, commercialization in retail cuts still increases in importance, 
with the loin and hind part being the most valuable cuts (HERNÁNDEZ et al. 2004). The carcasses of purebred and crossbred rabbits had a high meat content: from 80.0 to $80.4 \%$. OUHAYOUN (1992) found similar results comparing NZW and CAL rabbits. The proportion of bones in the carcasses ranged from 17.3 to $18.2 \%$. Our findings are similar to those of ORTIZ HERNÁNDEZ and RUBIO LOZANO (2001). The carcasses varied in fat content (1.3-2.5\%). A higher dissectible fat content in carcasses of CAL and crosses does not pose a problem, because the amount of fat in the rabbit carcass is very small, compared with other farm animals. Similar fat content in rabbits of synthetic line found HERNÁNDEZ et al. (1996). Higher fat content in NZW and CAL rabbits reported BIELAŃSKI (2004), lower BIENIEK (1997). The weights of the fore parts of carcass did not differ between the breeds, whereas the most valuable cuts (loin and the hind part of carcass) were poorer developed in purebred NZW, than in crosses and CAL purebred rabbits. A lack of significant effects of crossing on carcass traits could be partly explained by the similar origin of the NZW and CAL rabbits. CAL rabbits were bred from NZW - thus the genetic divergence is not expected to be large. In consequence also effects of crossing NZW and CAL rabbits were low, in particular on meat and carcass traits.

Dressing percentage was higher in the NZW $\times$ CAL crosses than in purebred rabbits and CAL $\times$ NZW crosses. Because of different calculation methods it is hard to compare our results with those obtained by other authors. In agreement with the present results, studies by OZIMBA and LUKEFAHR (1991), and HERNÁNDEZ et al. (2006), but BIELAŃSKI et el. (2004) reported a higher dressing percentage for CAL than NZW rabbits. By contrast, SKRIVANOVA et al. (2000) found a lower dressing percentage in the former than the latter. Comparing Hyplus hybrid, purebred Pannon White rabbits and their crossbreds METZGER et al. (2006) found a higher dressing percentage.

There were no significant differences between the sexes in the growth and slaughter traits. Other authors also reported no influence of sex on growth parameters and dressing percentage (ORTIZ HERNÁNDEZ and RUBIO LOZANO 2001).

In conclusion the reciprocal crosses of the NZW and CAL rabbits (NZW $\times C A L$ and CAL $\times N Z W$ ) were heavier than the purebred animals. NZW $\times C A L$ crosses attained the slaughter body weight earlier at a lower feed consumption. The dressing percentage in $\mathrm{NZW} \times \mathrm{CAL}$ crosses was highest, while the lowest in NZW rabbits. For other slaughter traits, except the fat content of carcass, effects of crossing rabbits were small. The magnitude of the crossbreeding effects depended on the direction of crossbreeding. Maximum effects in crosses for slaughter age, body weight, feed consumption and dressing percentage were obtained when the Californian breed was used as a maternal component.

\section{References}

Bielański P (2004) Effect of breed and management system on productive traits of broiler rabbits. Rocz Nauk Zoot 18, 1-86 [in Polish]

Bieniek J (1997) Influence of the genetic and environmental factors on the meat production of rabbits in traditional breeding conditions. Zeszyty Nauk AR w Krakowie Rozprawy 233, 1-149 [in Polish]

Dalle Zotte A (2000) Main factors influencing the rabbit carcass and meat quality. Proc of the 7th World Rabbit Congress Valencia Spain, 1-32

Dalle Zotte A (2002) Perception of rabbit meat quality and major factors influencing the rabbit carcass and meat quality. Livest Prod Sci 75, 11-32 
Gondret F, Combes S, Larzul C, De Rochambeu H (2005) The influence of divergent selection for body weight at 63 days of age in rabbits on muscle characteristics at a same age or at similar weight. Arch Tierz $48 \mathrm{SI}, 98-104$

Hernández P, Pla M, Blasco A (1996) Prediction of carcass composition in the rabbit. Meat Sci 44, 75-83

Hernández P, Aliaga S, Pla M, Blasco A (2004) The effect of selection for growth rate and slaughter age on carcass composition and meat quality traits in rabbits. J Anim Sci 82, 3138-43

Hernández P, Ariño B, Grimal A, Blasco A (2006) Comparison of carcass and meat characteristics of three rabbit lines selected for litter size or growth rate. Meat Sci 73, 645-50

Metzger SZ, Odermatt M, Szendrő Z, Mohaupt M, Romvári R, Makai A, Biró-Németh E, Radnai I, Sipos L (2006) Comparison of carcass traits and meat quality of Hyplus hybrid purebred Pannon White rabbits and their crossbreds. Arch Tierz 49, 389-99

Nofal RY, Toth S, Virag G (1997) Evaluation of seven genetic groups of rabbits for carcass traits. Arch Tierz $40,61-7$

Ortiz Hernández JA, Rubio Lozano MS (2001) Effect of breed and sex on rabbit carcass yield and meat quality. World Rabbit Sci 9, 51-6

Oseni S, Odubote I, Akinokun O, Somade B (1997) Productivity levels of three breeds of rabbits and their cross over a three year period in the humid tropics. Arch Tierz 40, 469-76

Ouhayoun J (1992) Rabbit meat. Cuni Sci 7, 1-15

Ozimba CE, Lukefahr SD (1991) Comparison of rabbit breed types for post weaning litter growth feed efficiency and survival performance traits. J Anim Sci 69; 3494-3500

Piles M, Blasco A, Pla M (2000) The effect of selection for growth rate on carcass composition and meat characteristics of rabbits. Meat Sci 54, 347-55

SAS (2001) SAS/STAT user's guide Release 8.2. Statistical Analysis System. SAS Institute Inc. Cary NC USA

Shahin KA, Hassan NS (2002) Changes in sources of shared variability of body size and shape in Egyptian local and New Zealand White breeds of rabbits during growth. Arch Tierz 45, 269-77

Shemeis AR, Abdallah OY (1998) Selection indexes for increased marketing body weight and advantageous body composition in New Zealand White rabbits. Arch Tierz 41, 597-605

Shemeis AR, Abdallah OY (2000) Possibilities of developing favourable body fat partition via selection indexes - application on rabbits. Arch Tierz 43, 193-201

Skřivanová V, Marounek M, Tumova E, Skrivan M, Lastovkova J (2000) Performance carcass yield and quality of meat in broiler rabbits a comparison of six genotypes. Czech J Anim Sci 45, 91-5

Received 29 November2008, accepted 28 January 2009.

Corresponding author:

Dr. DOROTA MAJ

email:dmaj@ar.krakow.pl

Department of Genetics and Animal Breeding, Agriculture University of Krakow, al. Mickiewicza 24/28, 30-059 Krakow, Poland 